\section{National Agricultural Advisory Service}

RECENT changes in the National Agricultural Advisory Service include the following : Mr. J. Butt. Evans, at present county advisory officer for Durham, to be county advisory officer for Yorkshire (North Riding), in succession to Mr. W. S. Rayfield, who was recently transferred to headquarters; $\mathbf{M r}$. G. P. Chater, at present hops adviser in the West Midland Region, to be director of the Rosemaund Experimental Husbandry Farm, Preston Wynne, Hereford, in succession to $\mathrm{Mr}$. E. L. Jones, who succeeds $\mathrm{Mr}$. W. R. Smith as one of the two livestock husbandry officers for Wales.

\section{American Geophysical Union : Officers}

THE triennial elections of the national officers of the American Geophysical Union have recently been held, and the following have been elected for a threeyear poriod from July 1 : President, Dr. Thomas F. Malone, director of research, Travelers Insurance Co., Hartford, Connecticut; Vice-president, Dr. Goorge P. Woollard, professor of geophysies, Department of Geology, University of Wisconsin; General Secretary, Dr. A. Nelson Sayre, senior scientist, U.S. Geological Survey, Washington, D.C.

\section{The Night Sky in May}

New moon occurs on May 14d. 16h. 55m. U.T. and full moon on May 30d. 04h. 38m. The following conjunctions with the Moon take place: May 6d. 12h., Saturn $3^{\circ}$ S.; May 7d. 00h., Jupiter $3^{\circ}$ S.; May 11 d. 16h., Venus $4^{\circ}$ N.; May 20d. 18h., Mars $4^{\circ}$ N.; May 22d. 13h., Regulus 0. $7^{\circ}$ N. In addition to these conjunctions with the Moon, Mercury is in conjunction with Aldebaran on May 15d. 22h., Mercury being $7^{\circ} \mathrm{N}$. Mercury is an evening star, and is visible in the west after sunset; on May 31 it sets about two hours after the Sun. Venus is a morning star, but it is too elose to the Sun for easy observation. Mars is an evening star, but conditions for observation are becoming less favourable. It sets about midnight; its stellar magnitude is +1.5 on May 15 , and its distance from the Earth on May 15 is 158 million miles. Jupiter rises at $1 \mathrm{~h} .40 \mathrm{~m}$., $0 \mathrm{~h} .50 \mathrm{~m}$. and $23 \mathrm{~h}$. $45 \mathrm{~m}$. on May 1, 15 and 31 , respectively. It is in Capricornus, its stellar magnitude on May 15 is $-\mathbf{2 . 0}$ and its distance from the Earth on that date is 440 million miles. Saturn rises at $1 \mathrm{~h} .20 \mathrm{~m}$., $0 \mathrm{~h} .45 \mathrm{~m}$. and $23 \mathrm{~h} .20 \mathrm{~m}$. at the beginning, middle and end of the month, respectively. It is near the border of Sagittarius and Capricornus; on May 15 its stellar magnitude is +0.7 and its distance from the Earth is 890 million miles. There is one occultation of a star brighter than magnitude 6 visible at Greenwich; May 2d. 23h. 16.6m., 24 Seo., reappearance.

\section{Announcements}

Prof. Jean Brachet (Brussels) and Prof. Hans Bauer (Wilhelmshaven) have been awarded the Schleiden Medal of the Leopoldina German Academy of Seience, for their outstanding work in the field of cytology.

DR. B. P. PAL, director of the Indian Agricultural Research Institute, New Delhi, has been awarded the first Rafi Ahmed Kidwai Memorial Prize of the Indian Council of Agricultural Research, for his work on the breeding of Pusa wheat varieties.

Mr. E. S. Calvert and Mr. J. W. Sparke, both of the Ministry of Aviation's Royal Aircraft Establish- ment, Farnborough, have been awarded the 1961 Laura Taber Barbour Air Safety Award, in recognition of their "major contribution to world air safety through joint development of the Line and Bar Approach Lighting System and the Visual Glide Path Indicator now installed and in use at many major airports". The Award is made annually by Flight Safety Foundation Award Inc., of the U.S. Society of Automotive Engineers Inc.

The Duke of Edinburgh will open the McFadzean Laboratory at the Wood Lane research centre of British Insulated Callender's Cables, Ltd., on May 16.

THE Bradford Institute of Technology is organizing a special short course on "Methods of Polymer Characterization and Analysis" during June 23-24. Further information can be obtained from the Registrar, Institute of Technology, Bradford 7.

THE Biology Department of Brookhaven National Laboratory is organizing a symposium on "Fundamental Aspects of Radiosensitivity" during June 5-7. Further information can be obtained from Dr. A. H. Sparrow, Brookhaven National Laboratory, Associated Universities Inc., Upton, L.I., N.Y.

Tre Applied Spectroscopy Group and the Manchester and District Branoh of the Institute of Physics and the Physical Society are holding a joint one-day meeting on "Spectroscopic Studies using Time Resolution Techniques", on June 16. Further information can be obtained from the Institute of Physics and the Physical Society, 47 Belgrave Square, London, S.W.i.

The International Academy of Astronautics of the International Astronautical Federation is organizing a symposium on "Space Flight and Re-entry Trajeetories" to be held in Paris during June 19-21. A number of symposia are planned, dealing with the following subjects: trajectories for lunar and interplanetary missions; orbital transfer and rendezvous; near-Earth satellites; dynamics of terminal re-entry. Further information can be obtained from the International Academy of Astronautics, 12 Rue de Gramont, Paris 2e.

The British Biophysical Society is organizing a meeting at the University of Nottingham during July 26-28. Two symposia are being organized: "Phloem Transport in Plants" and "Electron Transfer in Biological Molecules". There will also be a session for the reading of papers, and a discussion on "International Organization in Biophysics". Further information and application forms can be obtained from the honorary treasurer, Dr. P. M. B. Walker, Zoology Department, University of Edinburgh, West Mains Road, Edinburgh.

AN informal meeting is to be held at the Royal College of Science and Technology, Glasgow, on June 27, under the auspices of the Faraday Society, to mark the centenary of the publication by Thomas Graham of his paper on liquid diffusion, in which he distinguished between colloids and crystalloids. Mr. D. C. Henry, of Manchester, will preside, and speakers will include: Sir Eric Rideal, Prof. J. A. V. Butler, Dr. A. S. C. Lawrence and Dr. A. P. Prosser. Further information may be obtained from Dr. A. J. Hyde, Department of Chemistry, Royal College of Science and Technology, George Street, Glasgow, C.1. 